〔58 59〕共軸円筒型回転粘弾性計

第 1 報

(1958 年 10 月 3 日受理)

岩柳茂夫* ・中根平之助*

\begin{abstract}
要 旨研究室において使用する目的の下に，共軸円筒型回転粘度咶を設㖕試作した。定常粘性率の 測定のためには，内筒のプレーに重錘をか十，内筒の角速度を测るか，または外筒を一定速度で回転せしめ，内 筒に作用するトルクを測るかする。これを粘弹性計として使用する場合には，外筒を一定角振幅で振動せしめ これに半5内筒の振動を，一定速度で送られる印画紙の上に記録し，内外简の振動の振幅比と位相宦とを決定 し，これらからさらに試料の動的粘性率々動的ずれ弾性率上圭計箱する。振動数は $10 \mathrm{c} / \mathrm{s}$ まで。測定の実例 としてシリコーン油に関するもの在揭げる。
\end{abstract}

\section{1. 緒言}

粘性率の絶対的測定装置として共軸円筒型回転粘度計 は, 特に非ニュートン液体に関する測定に, その優越性 を示すことがよく知られている。近時はまた粘弾性測定 にも利用せられるようになり，著しい成果を収めつつあ る $^{11,2)}$ 。元来この型の装置は粘度計としては, 外筒を固 定し一定荷重による内筒の定常回転の速度を測る場合 と, 外筒を一定速度で回転せしめた際, 内筒に作用する トルクを測る場合とが多かった。粘弾性計として用いる 場合には，針金で吊された内筒の運動を観測するのであ るが，針金の上端を駆動するとき”と外筒に一定角振幅 の振動を与えるとき2)とがある。ここに述べようとする 装置は，上記のいずれの場合をも実行できるよう設計試 作したもので，実用的といらよりも研究室用である。

試作装置の性能テストの意味で本研究ではますシリコ ーン油を測定の対象にした。ここにあげる測定例に使用 したシリコーン油は, 信越化学製 KF $-96 \mathrm{H}, 10,000 \mathrm{cS}$ な らびに $100,000 \mathrm{cS}$ ののである。シリコーン油の粘弹性 に関する測定は 1952年 Markovitzら $3{ }^{3)}$ にって発表され ているので, 後述のように相互に比較することができた。 本装置には恒温装置の用意はしてあるが, さしあたり これを使用しなかった。したがってデータは $25^{\circ} \mathrm{C}$ 付近 の室温で得られたものである。これを $25^{\circ} \mathrm{C} に$ 換算して, しつのまとまった結果にするために Ferry の換算変数 の方法を利用した。その際必要な shift factor を計算 するのには，見かけの活性化エネルギーとして Markovitz ら)の $4.36 \mathrm{kcal} / \mathrm{mol}$ なる值を借用した。

\section{2. 試作装置の搆造（第 1 図，写真）}

\section{1 外筒}

ボールベアリングに保持された外筒 (9)はその上部が 広くなっており，最上部の外周辺にはV字型の清(6)が

\footnotetext{
* 理化学研究所 (東京都文京区上富士前町 31)
}

あり、この溝にベルトをかけて定常回転を行ならことが できる。外筒に一定振幅の振動角変位を与えて振動測定 在行ないたい場合には，(27）を支点として(水平方向で) 振動する楿 $(28)$ を，ピン (25) と連結片 (23) とにより外筒 に連結する。桿 $(28)$ にこのような振動を行なわせるに は、鉛㨁からわずかに傾いた斜面力么(39)に，桿の右端 に水平に取り付けた自由に回転しらる小円板 (29)をスプ リング(60)で押しつけて㧍き，力ム面を水平軸のまわり に一定速度で回転せしめる。今の場合外筒の角変位は, その振幅が約 $1^{\circ} 7^{\prime}$ といら小さな值しかとらないから，十 分正弦運動に近似するものと考えられ, 実際に振動数

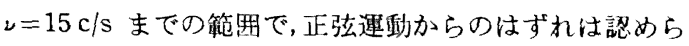
れなかった。振幅を広く変化する装置は設けてない。

\section{2 内 筒 I}

内筒 (16)はその細くなった上部(17)で，固定されただ アリングケース中のボールベアリングに保持せられ，下 端面のピボット受け(14)で外筒の底面にあるピポット (15)に乗る。種々の太さの連結スチール棒，あるいは鋼 線が、下端を $5 \mathrm{~mm}$ の太さにして, 内筒の最上端の穴の 中心ピス止めされ，上端を(罒に示してない)ドリルチャ

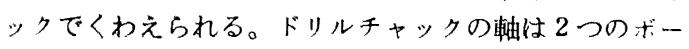
ルベアリングに保持せられ,プレー(46)が備えてあって, これに一定の荷重をかけてドリルチャック，したがって 内筒を定常回転させることができる(この際て沈もちろ ん外筒は固定され，連結スチール棒としては十分太いる のを使用する)。外筒を運動させる場合には，此め金 (61)-(65)によって，あるい㭭に用意したネジよっ て、プレー(46) を固定する。この際の連結スチール棒の

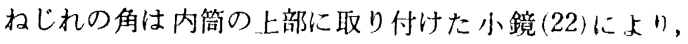
望遠鏡と尺度の方法で読まれる。

\section{3 組立て}

外筒を保持するボールベアリングを入れるケース(5) は，金属容器(1)の中央に固它されこの谷寧のフタ(38) に注内筒を保持するぐアリングを入れるケース (19) 占よ 


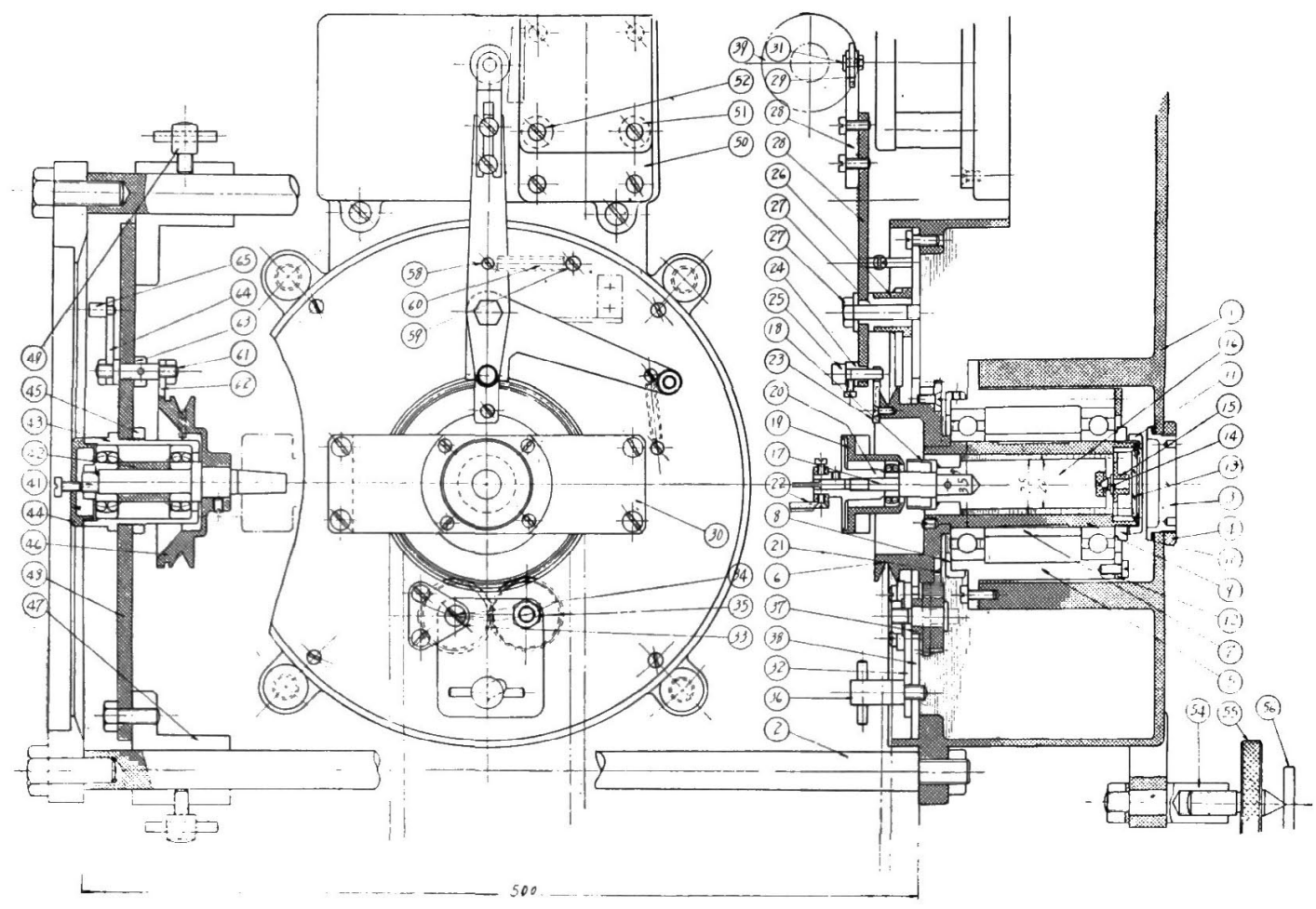

第 1 図 装置の組立て図, (32)〜 (37) は外简をギャーで駆動する装置

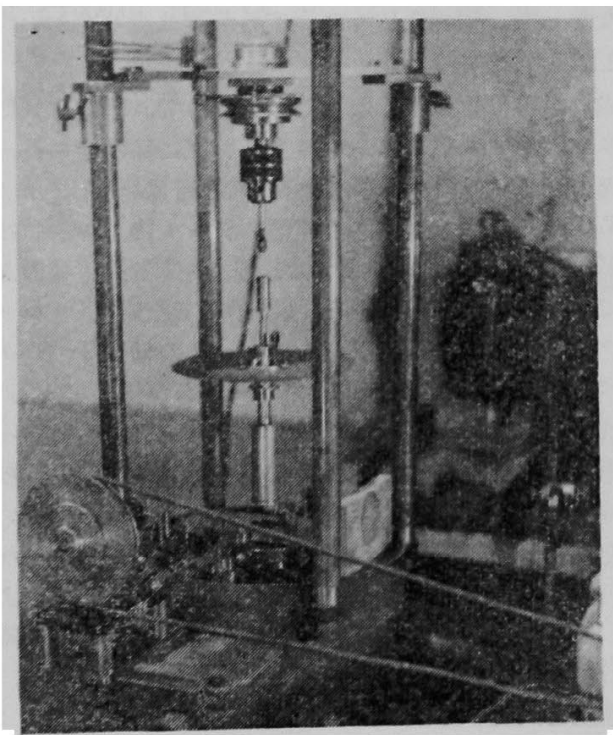

写真 1 回転粘弹性計の主要部分内筒を引き 上げたところを示す。

び外筒の首振り運動在駆動するための桿の支点 $(27)$ が取 り付けてある。またペアリングケース(43) は梁(48)に固
定され，この梁は 2 本の支柱(2)を案内として上下に移 動し, 適当な位置にネジ(49)によって固定される。

外筒の底面は取りはずしができ, かつ容器(1)の底か ら内外筒間の間吵をのぞいて，内筒の正しく位置してい ることを確かめることができるように，外筒および容器 にはガラス板の空 $(3,13)$ がつけてある。容器 $(1)$ には油 在入れて恒温槽にすることができる。

\section{4 内 筒 II}

振動測定の場合とか, 定常回転でも低応力レ心゙ルでの (特に外筒を句転させて鋼線のねじれ角による) 測定の場 合とかには，上述のような内筒 I では，上部のボールぐ アリンク゚と下端のピボットにおける摩擦がじやまにな る。そのような場合には, したがって細い鋼線で自由に 吊された，第 2 図に示したような内筒 II を使用する必要 がある。これは有効部分の半径は I と同じであるが, 上 部はIよりも細くしてあり，かつ底面に拈ける外筒との 間隔はやや広くなっている。使用状態ではピボットから 浮加す。

\section{5 慣性モーメント円板}

第 2 図の (71) (72) (73)は, 別々に取りはずしのできる 慣性モーメント円板で, これをつけた際に支点が重心よ りなるべく上になるよら連結棒 (74) を介して吊す。 


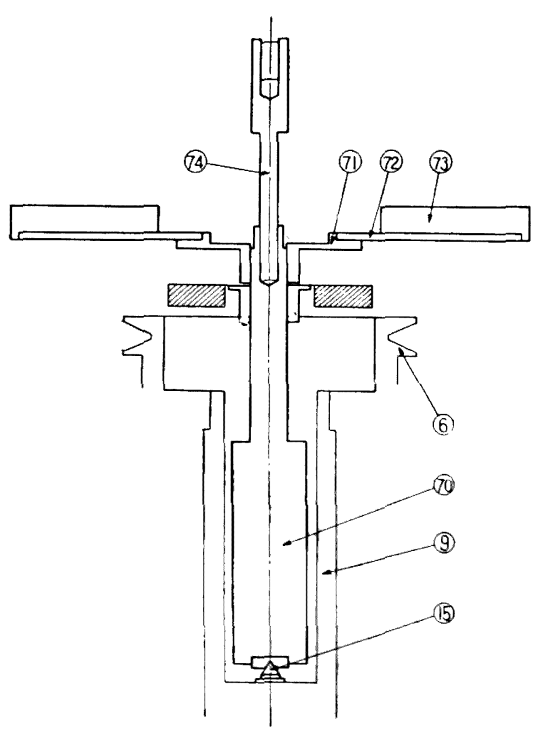

第 2 図内筒 II と慣性モーメント用円板

\section{6 酗動装置}

定常回転の場合の外筒の歌動，および振動実験の場合 のカム面の駆動には， 3 段のプレーを備えた 2 様の速度 $(240$ と $480 \mathrm{rpm})$ で回転しうるホニックモーターによっ て大体をまかなったが，不足のところは $1 / 100$ に減速し たシリースモーターによって補った。回転速度あるいは 振動数の小さいところではこれにさらに 3 段プレーと ウォームギァーとからなる減速器を仲介に使用した。

\section{7 回転数計}

外筒の回転数が大きい場合には，回転数をストップウ オッチだけで簡単に測ることはできなくなる。約 $1 \mathrm{rev} /$ sec 以上では光電管増幅器と録数器とを使用した回転数 計によった。

\section{3. 外筒の定常回転による粘性率の測定}

外简在一定角速度 $\Omega$ で回転したとき, 試料が内筒に及 ぼすトルク $M$ は

$$
M=4 \pi h \begin{gathered}
R_{1}{ }^{2} R_{2}{ }^{2} \\
R_{2}{ }^{2}-R_{1}{ }^{2}
\end{gathered} \cdot \eta \Omega
$$

ここに $R_{1}, R_{2}$ は内外筒の半径, $h$ は内筒の有効高さ, クは試料の粘性率で与えられる。一方このトルク $M$ は， 内筒を吊す針金のスティフネス $k$ と観測されるねじれの 角 $\Theta$ との積

$$
M=k \Theta
$$

で与えられる。今の場合 $R_{1}=1.00 \mathrm{~cm}, R_{2}=1.25 \mathrm{~cm}$, $h=6.00 \mathrm{~cm}$ であるから, (1), (2) 式により

が得られる。

$$
k \Theta=210 \eta \Omega
$$

このスティフネス $k$ を測定するには，振動実験用の惯 性モーメント円板を今の場合にも内筒に取り付けておき (こうすることにより好ましくない動摇を減少させるの にも役立つ), 空気中で振動させて, その固有振動数 を知り,

$$
k=4 \pi^{2} \nu_{0}{ }^{2} I
$$

(ここに I は慣性モーメント円板と内筒などの慣性モ ーメント)

から計算することができる。実際に使用した吊り線の值 径は $2.00,1.40,1.00,0.700,0.287 \mathrm{~mm}$, 有效長法 $2 \sim 1 \mathrm{C}$ $\mathrm{cm}$ であった。回転角 $の$ 测定はすべて尺度と望遠鏡の 方法によった。

共軸円筒型装置では試料がニュートン液体ならば，中 心から の距離におけるずれ速度 $\dot{\gamma} は$

$$
\frac{\dot{r}}{\Omega}=\frac{2}{r^{2}} \cdot \frac{R_{1}^{2} R_{2}^{2}}{R_{2}^{2}-R_{1}^{2}}
$$

で与えられ，試料中で一様ではない。しかしながら今の 場合のように，内外筒間の間隙の狭い装置 $\left(\left(R_{2}-R_{1}\right) / R_{1}\right.$ $=0.25)$ では,この不均一性もあまり著しくない。したが って試料が非ニュートン液体の場合にも，粘性率は (1) 式により計算し，この值をもって角速度 $\Omega$ に対応する粘 性率の值とすることができる。 $\Omega$ に対応するずれ速度と しては (5) 式の適当な平均值を用いれば十分である。こ こでは $\left\langle 2 / r^{2}\right\rangle=1 / R_{1}{ }^{2}+1 / R_{2}{ }^{2}$ としたので

$$
\langle\dot{\gamma}\rangle=4.55 \Omega
$$

外筒の定常回転による KF-96H, $10,000 \mathrm{cS}$ 抗よび $100,000 \mathrm{cS}$ シリコーン油に関する粘性測定の結果を第 3 図に示す。図に見られるように雨対数方眼紙に目盛った

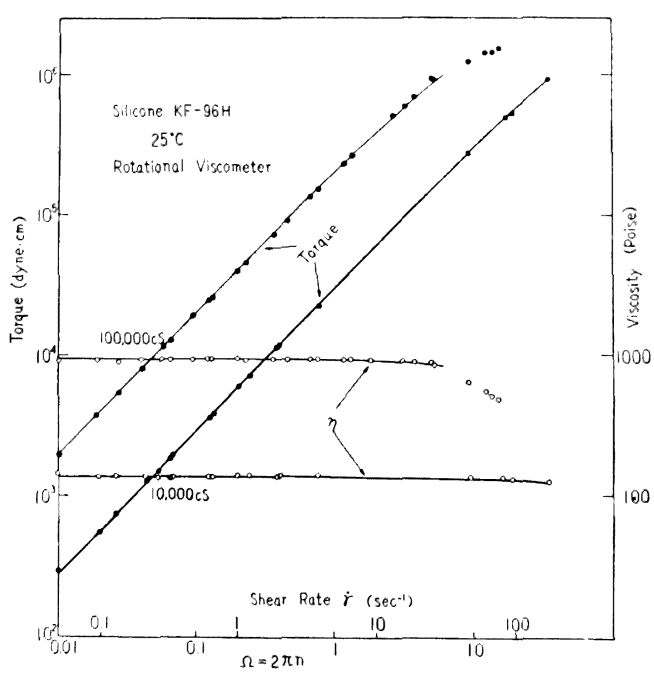

第 3 図 2 種のシリコーン油の定常粘性率 のずれ速度による変化 
際，トルク $M$ は角速度 $\Omega$ に対して， $\Omega$ の大きい方の端 を除いて, 正確に $45^{\circ} \mathrm{C}$ の傾斜をもつ直線をなす。これ らの值線の $\Omega=1\left(\mathrm{sec}^{-1}\right)$ に対する $M(\mathrm{dyn} \cdot \mathrm{cm})$ の值を

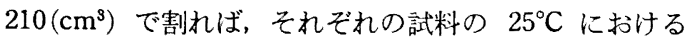
粘性率が 134,930 poise と計算される。

粘性率の小さな方のシリコーン油では $\Omega=10 \mathrm{sec}^{-1}$ $\left(\dot{\gamma}=50 \mathrm{sec}^{-1}\right)$ 以上, 粘性率の大きな方では $\Omega=1 \mathrm{sec}^{-1}$ $\left(\dot{r}=5 \mathrm{sec}^{-1}\right.$ ) 以上の角速度 (ずれ速度) で $\log M$ 対 $\log \Omega$ の直線は下方に曲り，したがって粘性率りはそれぞれ上 記の值から低下し始める(第 3 図)。

ずれ速度を上記以上にするために，もっと回転数を多 くすると， $10,000 \mathrm{cS}$ シリコーン油はきわめて細い系状 になって外へ飛散するようになり，100,000 cS シリュー ン油は著しいthixotropy（外筒の回転を始めてから後卜 ルクがゆっくり減少してゆき, 相当数の回伝を経て, は じめて一定值に落ちつく。しかもある休止時問をおけば 同じことを繰り返すことができる。）を示すようになるの で確かな測定が不可能になる。シリコーン油の非ニュー トン粘性を明らかにするためには，したがって内外筒間 の間隙をもっと狭くすることによってずれ速度を大きく する必要がある。

\section{4. 振動粘性率ならびにすれ弾性率の測定}

振動粘性率 $\eta^{\prime}$ とずれ弾性率 $G^{\prime}$ との測定には, 一定振 幅で外筒を回転振動せしめたとき，これにつれて起る内 筒の振動の振幅と外筒の振幅との比 $m$ と位相のおくれ めとを知る必要がある。このために電磁オシログラフの 光学箱を利用し, 一定速度で送られる印画紙の上に内外 筒の振動を並へてて記録することにした。両者の振動を直 角方向に合成してリサージュ図形を描かせる方法 ${ }^{1}$ に比 ベれば，実験装置はやや簡単といいうる。

内筒の慣性モーメント円板の下に小鏡をはりつけ，外 筒に固定した小鏡过適当なアームによりこれと並ぶよう にする。これら小鏡の前に焦点距㰚 $1 \mathrm{~m}$ の凸レンズを おき，光源の像を印画紙の上に結ばせる。外筒の一定角 振幅約 $1^{\circ} 7^{\prime}$ に対する印画紙上の振幅は $49 \mathrm{~mm}$ であっ た。オシログラフに付属する $1 / 100$ 秒の time mark, あ るいは同じランプを $1 / 5,1 / 2,1$ 秒おきに明滅させて得ら れる time mark を同一印画紙上に描かせて, 振動数っ (ならびに位相差 $\phi) の$ 測定に利用した。

外筒の一定振幅に対して内简の振幅 (すなわち振幅比 m)がいかに振動数に依存するかは、試料によってさま ささな゙ある。第 4 図に示されるように試料が液体に近い $\left(\omega r^{\prime} / G^{\prime} \gg 1\right)$ 場合には, 振幅比は内筒の固有振動数 $\nu_{0}$ で 最大になり，その両側で対称的に減少する。弾性的要素 の勝った試料でならば， $m$ の最大は $\nu_{0}$ とは異なったと ころに，m>1 となって現われる。

测定にあたっては惯性モーメントI と吊り線のスティ
フネス $k$ との組合せを適当にして，広い振動数範囲をお おいらるようにする。実際に使用した慣性モーメントの 值は，その幾何学的形状から計算して，次のごときもの である :
(71)だけをつけて
$I=0.254 \times 10^{3} \mathrm{~g} \cdot \mathrm{cm}^{2}$
(71) と銅円板をつけて $=1.98 \quad$ "
(71),(72)をつけて $I=5.79 \times 10^{3} \mathrm{~g} \cdot \mathrm{cm}^{3}$
(71),(72),(73)をつけて $=28.4$

ここで銅円板といったのは，第 2 困に示してないが外径 $13.6 \mathrm{~cm}$, 内径 $3.65 \mathrm{~cm}$, 厚さ $5.84 \mathrm{~mm}$ のものである。 吊り線としては種々の太さのピアノ線をさまざまの長さ で用いた。

試料の慣性が無視できるならば，実測される $m, \phi か$ ら $G^{\prime}, \eta^{\prime}$ 算出する式 ${ }^{2)}$ は

$$
\omega \eta *\left(\frac{1}{m} \cos \phi-1+\frac{i}{m} \sin \phi\right)=i A_{1} \cdot 4 \pi^{2}\left(\iota^{2}-\nu_{0}^{2}\right)
$$

ここで $\eta^{*}$ は複素粘性率 $\left(\omega \eta^{*}=\omega \eta^{\prime}-i G^{\prime}\right), \nu=\omega / 2 \pi$ は 測定の振動数, $\nu_{0}$ は内筒(を空気中で振動せしめたとき) の固有振動数, $A_{1}$ は装置の定数で

$$
A_{1}=I \cdot \frac{R_{2}{ }^{2}-R_{1}{ }^{2}}{4 \pi h R_{1}{ }^{2} R_{2}{ }^{2}}=\frac{I}{210}
$$

で与えられる。

第 4 図には $10,000 \mathrm{cS}$ シリコーン油に関して上記のよ らにして得られた $G^{\prime \prime}\left(\equiv \omega \eta^{\prime}\right), G^{\prime}, \eta^{\prime}$ と振動数 ととの関 係を示す。測定振動数籁囲 $0.1 \sim 10 \mathrm{c} / \mathrm{s}$ の間で，振動粘 性率は振動数によらず一定值 $\eta^{\prime}=140$ poise をとり,こ の試料の定常粘性率 $\eta=134$ poise と大体一致している (ともに端面の補正を差引いてない)。したがって $\log G^{\prime \prime}$ は $\log \nu$ 軸を正確に $45^{\circ} \mathrm{C}$ の傾きをなす直線となる。 $\log G^{\prime}$ はこれよりもやや傾斜の急な直線上にのるとみら れるが，测定精度が墨く，測定点がばらついている。こ れはこの测定箱囲で $(1 / m) \cos \phi-1$ が 0 に近い值をと る結果である。

この測定結果は Markovitz ら 用いて整理したデータと測定振動数籁囲つ重なっている $1 \sim 10 \mathrm{c} / \mathrm{s}$ 間で良い一致を示している。これは彼らの使 用したシリコーン油 DC $200(12,500 \mathrm{cS})$ が粘性率の点で 偶然にも第 4 図のものとほとんど等しいのであるから, 当然のことであるともいえる。振動粘性率 $\eta^{\prime}$ が振動数 レによって変化するような測定例については, 高エネル ギー放射線によって照射されたシリコーン油に関するも のを別の機会に日) すでに報告した。

なおここに述べた振動粘性率と，ずれ弾性率つ測定装 置は最近発表された Nielsenら”のものと測定原理にお いても振動数籁囲においてもきわめて類似していること を付記しておきたい。 


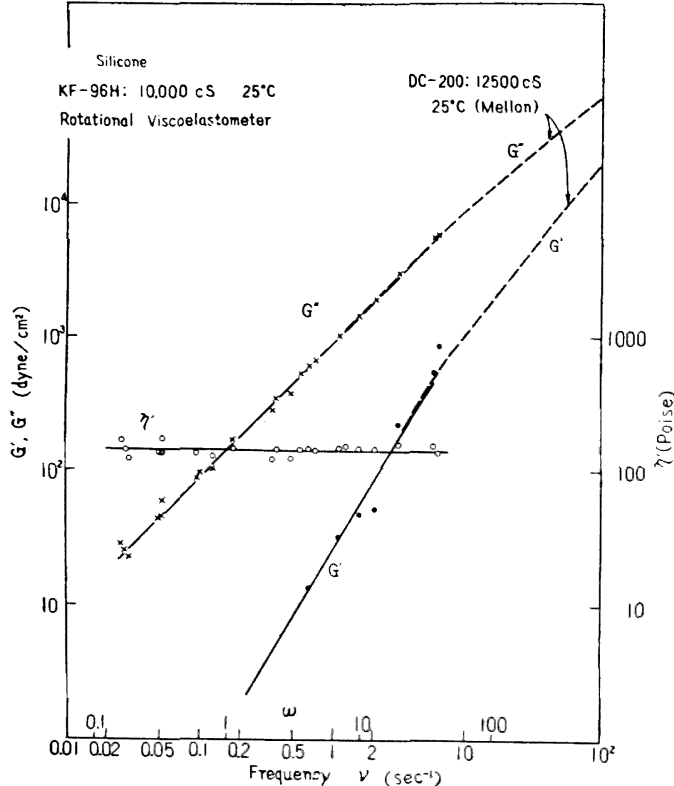

第 4 図シリコーン油の振動粘弾性率 $\eta^{\prime}$ と ずれ弾性率 $G^{\prime}\left(G^{\prime \prime} \equiv \omega, r^{\prime}, \omega=2 \pi \nu\right)$

\section{1 試料の䁬性に基く補正}

測定された $m, \phi$ から $G^{\prime}, \eta^{\prime}$ を計算するために用い た (7) 式には試料の慣性が考虑されていない。これを考 虑に入れた場合の解は岡氏ら によって得られている。試料の密度のの入った項の無視
できるための一般的条件は $\rho R^{2} \omega^{2} / G^{*}$ (ここで $R$ は内外 筒の半径程度の長さ， $G^{*}$ は複素ずれ弾性率)が 1 に比へ て十分小さいことであり，かつのを無視したための誤差 はまず $G^{\prime}$ の方に現われる。われわれの装置のディメン ションで振動数籁囲の最高限 $10 \mathrm{c} / \mathrm{s}$ でも， $10,000 \mathrm{cS}$ シ リコーン油の $G^{\prime}$ に対して，この誤差は数\%をこえない ことが計算される。G これは問題とするに足りない。

付 記：本論文の内容については日本物理学会昭和 31 年秋季分科会(京都)に㧍いて請演した。装圆の設計製作には当 研究所試作工場をわずらわした。また一部の測定には実習生芳 贺雄彦君があたった。陚料シリコーン油に関しては信越化学工 業株式会社桃井希義氏ならびに教育大学小寺明教授から多くの 教示を得た。終りにのぞみ上記諸氏とこの研究に対して温き援 助と有益な注意を与えられた研究室主任菅義夫教授とその研究 室の諸員に対して哚甚な感謝の意を表わす次第である。

\section{文}

献

1) T. Nakagawa and M. Seno: Bull. Chem. Soc. Japan, 29, 471 (1956)

2) H. Markovitz, et al: Rev. Sci. Instr., 23, 430 (1952)

3) R.C. Harper, H. Markovitz and T.W. DeWitt: J. Polym. Sci., 8, 435(1952)

4) W.P. Cox, L.E. Nielsen and R. Keeney : J. Polym. Sci., 26, 365 (1957)

5）岡小天，高見昭：小林理研報占，3，9，109(1935)

6) 岩柳, 秀島, 中根：第 2 回原子カシンポジウム報文 集，(1958)，高分子学会第 7 回年次大公講演要旨集， (昭 33 年 6 月)

\title{
Rotational Viscoelastometer of Coaxial Cylinder Type
}

\author{
By Shigeo Iwayanagi and Heinosuke Nakane
}

The construction of a versatile viscometer of coaxial cylinder type is described. The apparatus can be used (i) not only as a viscometer by hanging a weight on a pulley attached to the inner cylinder and observing its rotation velocity or by rotating the outer cylinder uniformly and measuring the torque exerted on the inner cylinder, (ii) but also as a viscoelastometer by setting the outer cylinder in rotatory oscillation and recording optically the oscillatory motion of the inner cylinder, thus enabling us to evaluate the amplitude ratio and phase difference between these two motions and therefrom the dynamic viscosity and rigidity of a specimen in a frequency range up to $10 \mathrm{cps}$. Some results of preliminary measurements on silicone oils are presented as examples. 